\title{
Prediction of Incompatibility of Ceftriaxone Sodium with Calcium Ions Using the Ionic Product
}

\author{
Yuka NAKaI, ${ }^{a, b}$ Emi ToKUyama, ${ }^{a}$ Miyako YoshidA, ${ }^{a}$ and Takahiro UCHIDA ${ }^{*, a}$ \\ aSchool of Pharmaceutical Science, Mukogawa Women's University, 11-68 Koshien 9-Bancho, \\ Nishinomiya 663-8179, Japan, and bepartment of Pharmacy, Bell Land General \\ Hospital, 500-3 Higashiyama Naka-ku, Sakai 599-8247, Japan
}

(Received May 16, 2009; Accepted September 11, 2009)

\begin{abstract}
The purpose of this study was to evaluate the incompatibility of ceftriaxone sodium with calcium-containing products using the ionic product of precipitation, and the measurement of insoluble microparticles using a light obscuration particle counter. Appropriate volumes of $2 \%(\mathrm{w} / \mathrm{v})$ calcium chloride solution were added to $0.4-2 \mathrm{mg} / \mathrm{ml}$ ceftriaxone isotonic sodium chloride solution, to make solutions with a final calcium ion concentration of $1.25 \mathrm{mmol} / 1$. The solutions were gently agitated and stored at $37^{\circ} \mathrm{C}$ for $24 \mathrm{~h}$. The number of insoluble microparticles with a diameter less than $10 \mu \mathrm{m}$ in the mixed sample solution, determined using a light obscuration particle counter, was increased when the ceftriaxone concentration was $\geq 0.8 \mathrm{mg} / \mathrm{ml}$. The Saturation Index (defined as the ratio of the ionic product to the solubility product constant) of the prepared mixed solution was 1.1. A white precipitate could be observed visually when the ceftriaxone concentration of the sample solution was $7 \mathrm{mg} / \mathrm{ml}$; the Saturation Index of the solution was 9.7. The effect of the calcium source on incompatibility with ceftriaxone sodium was also evaluated. The numbers of insoluble microparticles in sample solutions made by adding calcium chloride to the sample were significantly higher than those made by adding calcium gluconate. These results suggest that ceftriaxone should not be co-administered with calciumcontaining products even if no precipitation is observed visually. There will still be insoluble microparticles caused by incompatibility in the sample solution when the Saturation Index of the solution is over 1.0.
\end{abstract}

Key words_— ceftriaxone; calcium; incompatibility; ionic product; insoluble microparticle; light obscuration particle counter

\section{INTRODUCTION}

A varied amount (33-67\%) of a ceftriaxone dose is excreted in the urine as unchanged drug, while the remainder is secreted in the bile and ultimately found in the feces as microbiologically inactive compounds. After a $1 \mathrm{~g}$ intravenous dose of ceftriaxone, the average tissue concentrations determined $1-3 \mathrm{~h}$ after dosing were $581 \mu \mathrm{g} / \mathrm{ml}$ in the gallbladder bile, $788 \mu \mathrm{g} /$ $\mathrm{ml}$ in the common bile duct, $898 \mu \mathrm{g} / \mathrm{ml}$ in the cystic bile duct, $78.2 \mu \mathrm{g} / \mathrm{ml}$ in the gallbladder wall, and 62.1 $\mu \mathrm{g} / \mathrm{ml}$ in the plasma, as described in a previous article. ${ }^{1)}$

In 2007 , the US FDA issued a safety alert ${ }^{2}$ on the interaction of ceftriaxone with calcium-containing products, due to a number of neonatal deaths caused by ceftriaxone-calcium precipitates in lungs and kidneys. Cases of biliary concretions or sludge have been reported as adverse events associated with the interaction of ceftriaxone with calcium-containing products;

*e-mail: takahiro@mukogawa-u.ac.jp these events are mentioned in the package insert. It was recommended that ceftriaxone should not be mixed with calcium-containing products and not administered in the same or different infusion lines or sites in any patient within $48 \mathrm{~h}$ (given the long halflife of ceftriaxone). Symptomatic biliary sludge made of ceftriaxone has frequently been observed in children, ${ }^{3-5)}$ and abnormal gallbladder sonograms were demonstrated in $17.3 \%$ of children receiving high doses of ceftriaxone to treat infection. ${ }^{6}$ There is also a report in an adult without gall bladder inflammation. ${ }^{\text {) }}$

According to a study of the interaction from the standpoint of solubility, ${ }^{8)}$ although the theoretical solubility product constant K'sp (defined as the maximum solubility) for ceftriaxone-calcium salt was 1.62 $\times 10^{-6} \mathrm{~mol}^{2} / 1^{2}$, precipitates were observed at an ionic product, $\left[\mathrm{Ca}^{2+}\right] \times\left[\mathrm{C}_{18} \mathrm{H}_{15} \mathrm{~N}_{8} \mathrm{O}_{7} \mathrm{~S}_{3}^{3-}\right]$, of $1.69 \times 10^{-5}$ $\mathrm{mol}^{2} / \mathrm{l}^{2}$, more than 10 -fold greater than $\mathrm{K}$ 'sp, that is, the Saturation Index (defined as the ratio of the ionic product to K'sp) was 10 . The area between K'sp and the observed ionic product at which precipitate 
forms, defines the metastable zone for ceftriaxonecalcium salt solubility.

In this study, the incompatibility of ceftriaxone sodium for injection and calcium-containing products was evaluated from the viewpoint of solubility by measuring the number of insoluble microparticles using a light obscuration particle counter.

\section{EXPERIMENTAL}

Materials $\quad$ Rocephin ${ }^{\circledR}$ for injection containing 1 g ceftriaxone (Chugai Pharmaceutical Co., Ltd., Tokyo, Japan), and $100 \mathrm{ml}$ isotonic sodium chloride solution (Terumo Co., Ltd., Tokyo) were purchased for use in this study. As calcium-containing injections, $20 \mathrm{ml}$ calcium chloride injection 2\% (Otsuka Pharmaceutical Co., Ltd., Tokyo) and Calcicol ${ }^{\circledR}$ (Dainippon Sumitomo Pharma Co., Ltd., Osaka, Japan) were also purchased. Further, as calcium-containing solutions, $500 \mathrm{ml}$ Solacet ${ }^{\circledR} \mathrm{F}, 500 \mathrm{ml}$ Solulact ${ }^{\circledR}$, $700 \mathrm{ml}$ Hicaliq ${ }^{\mathbb{B}}-2$ (Terumo Co., Ltd.), $1000 \mathrm{ml} \mathrm{Ne}$ oparen $_{\circledast}$ No.1, $1000 \mathrm{ml}$ Neoparen $\otimes$ No.2, $500 \mathrm{ml}$ Bfluid $_{\circledast}$ (Otsuka Pharmaceutical Co., Ltd.), $500 \mathrm{ml}$ Solitax ${ }^{\circledR}-\mathrm{H}$, and $500 \mathrm{ml}$ Bicarbon ${ }^{\circledR}$ (Ajinomoto Pharma Co., Ltd., Tokyo) were also purchased.

Measurement of Insoluble Microparticles Using a Light Obscuration Particle Counter The employed method was essentially the same as the 'Insoluble Particulate Matter Test for Injection Method 1. Light Obscuration Particle Count Test' described in the 15th edition of the Japanese Pharmacopoeia (2006) .9)

All procedures were carried out at a clean bench. The number and size of microparticles were determined using a light obscuration particle counter KL04 (RION Co., Ltd.). The thresholds of microparticle size were 1.3, 2.0, 5.0, 10.0, 20.0, 25.0, 40.0, 50.0, and $100.0 \mu \mathrm{m}$. The volume of each sample was $5 \mathrm{ml}$, and the mean value of three sample measurements was calculated. All instruments were washed with water after sample injection to eliminate insoluble microparticles derived from the devices.

The results of the incompatibility of ceftriaxone sodium for injection with calcium-containing solutions were evaluated according to the criteria for the maximum allowable number of insoluble microparticles in the 15th edition of the Japanese Pharmacopoeia. For injection preparations administered at a volume over $100 \mathrm{ml}$, the tolerated number of insoluble microparticles with a diameter $10 \mu \mathrm{m}$ or greater is 25 or less, while that of microparticles with a diameter $25 \mu \mathrm{m}$ or greater is 3 or less, per $\mathrm{ml}$.

Calculation of Concentration of Ceftriaxone Ion

The concentration of ceftriaxone ion $\left[\mathrm{C}_{18} \mathrm{H}_{15} \mathrm{~N}_{8} \mathrm{O}_{7}\right.$ $\mathrm{S}_{3}^{3-}$ ] was calculated by,

$$
\begin{aligned}
{\left[\mathrm{C}_{18} \mathrm{H}_{15} \mathrm{~N}_{8} \mathrm{O}_{7} \mathrm{~S}_{3}^{3-}\right] } & \\
= & \mathrm{Ka}_{1} \cdot \mathrm{Ka}_{2} \cdot \mathrm{Ka}_{3} \cdot\left[\mathrm{C}_{18} \mathrm{H}_{18} \mathrm{~N}_{8} \mathrm{O}_{7} \mathrm{~S}_{3}\right] /\left(\left[\mathrm{H}^{+}\right]^{3}\right. \\
& +\left[\mathrm{H}^{+}\right]^{2} \cdot \mathrm{Ka}_{1}+\left[\mathrm{H}^{+}\right] \cdot \mathrm{Ka}_{1} \cdot \mathrm{Ka}_{2}+\mathrm{Ka}_{1} \\
& \left.\cdot \mathrm{Ka}_{2} \cdot \mathrm{Ka}_{3}\right)
\end{aligned}
$$

where $\left[\mathrm{C}_{18} \mathrm{H}_{18} \mathrm{~N}_{8} \mathrm{O}_{7} \mathrm{~S}_{3}\right]$ is the total concentration of ceftriaxone and,

$$
\begin{array}{r}
\mathrm{Ka}_{1}=\left[\mathrm{H}^{+}\right]\left[\mathrm{C}_{18} \mathrm{H}_{17} \mathrm{~N}_{8} \mathrm{O}_{7} \mathrm{~S}_{3}^{-}\right] /\left[\mathrm{C}_{18} \mathrm{H}_{18} \mathrm{~N}_{8} \mathrm{O}_{7} \mathrm{~S}_{3}\right] \\
\mathrm{Ka}_{2}=\left[\mathrm{H}^{+}\right]\left[\mathrm{C}_{18} \mathrm{H}_{16} \mathrm{~N}_{8} \mathrm{O}_{7} \mathrm{~S}_{3}^{2-}\right] /\left[\mathrm{C}_{18} \mathrm{H}_{17} \mathrm{~N}_{8} \mathrm{O}_{7} \mathrm{~S}_{3}^{-}\right] \\
\mathrm{Ka}_{3}=\left[\mathrm{H}^{+}\right]\left[\mathrm{C}_{18} \mathrm{H}_{15} \mathrm{~N}_{8} \mathrm{O}_{7} \mathrm{~S}_{3}^{3-}\right] /\left[\mathrm{C}_{18} \mathrm{H}_{16} \mathrm{~N}_{8} \mathrm{O}_{7} \mathrm{~S}_{3}^{2-}\right]
\end{array}
$$

The pKa of ceftriaxone are $\mathrm{pKa}_{1}=1.72, \mathrm{pKa}_{2}=3.15$, $\mathrm{pKa}_{3}=4.34$.

Prediction of Incompatibility Using the Ionic Product and K'sp

Measurement of Insoluble Microparticles The plasma concentration of ionized calcium was postulated to be $1.25 \mathrm{mmol} / \mathrm{l}$. When the calcium ion concentration was fixed at $1.25 \mathrm{mmol} / \mathrm{l}$, if the ceftriaxone concentration was assumed to be $0.8 \mathrm{mg} / \mathrm{ml}$ or higher, $\left[\mathrm{Ca}^{2+}\right] \times\left[\mathrm{C}_{18} \mathrm{H}_{15} \mathrm{~N}_{8} \mathrm{O}_{7} \mathrm{~S}_{3}^{3-}\right]$ exceeded $\mathrm{K}$ 'sp for ceftriaxone-calcium salt. Appropriate volumes of $2 \%(\mathrm{w} / \mathrm{v})$ calcium chloride solution were added to 0 , $0.4,0.8,1.2,1.6$, or $2 \mathrm{mg} / \mathrm{ml}$ ceftriaxone isotonic sodium chloride solution, to make solutions with a final calcium ion concentration of $1.25 \mathrm{mmol} / \mathrm{l}$. The solutions were gently agitated and stored at $37^{\circ} \mathrm{C}$ for $24 \mathrm{~h}$, at which point the reaction of ceftriaxone and calcium had reached a state of equilibrium. The numbers of insoluble microparticles were measured $24 \mathrm{~h}$ after sample preparation, according to the method described in the previous section.

Judgment of Precipitation by Visual Observation

Appropriate volumes of $2 \%(\mathrm{w} / \mathrm{v})$ calcium chloride solution were added to $1,3,5,7,8$ and $10 \mathrm{mg} / \mathrm{ml}$ ceftriaxone isotonic sodium chloride solution, to make solutions with a final calcium ion concentration of $1.25 \mathrm{mmol} / \mathrm{l}$. The solutions were gently agitated and stored at $37^{\circ} \mathrm{C}$ for $24 \mathrm{~h}$. The mixtures were observed visually $24 \mathrm{~h}$ after sample preparation.

Identification of Precipitate Caused by Incompatibility Appropriate volumes of $2 \%(\mathrm{w} / \mathrm{v})$ calcium chloride solution were added to $10 \mathrm{mg} / \mathrm{ml}$ 
ceftriaxone isotonic sodium chloride solution, to make solutions with a final calcium ion concentration of $2.5 \mathrm{mmol} / \mathrm{l}$. The solutions were gently agitated and stored at $25^{\circ} \mathrm{C}$ for $6 \mathrm{~h}$. The elementary analysis of samples was done after filtration and drying under reduced pressure by an Instrument for Organic Elemental Micro Analysis (Chncorder MT-3, Yanagimoto Mfg Co., Ltd.) .

Incompatibility of Ceftriaxone with Calcium Chloride and Calcium Gluconate Solutions

Measurement of Insoluble Microparticles Appropriate volumes of $2 \%(\mathrm{w} / \mathrm{v})$ calcium chloride solution or $8.5 \%(\mathrm{w} / \mathrm{v})$ calcium gluconate solution were added to $10 \mathrm{mg} / \mathrm{ml}$ ceftriaxone isotonic sodium chloride solution, to make solutions with a final calcium ion concentration of $0.5,1,1.5,2$ and $2.5 \mathrm{mmol} /$ 1. The solutions were gently agitated and stored at 20 ${ }^{\circ} \mathrm{C}, 25^{\circ} \mathrm{C}$ or $30^{\circ} \mathrm{C}$. The numbers of insoluble microparticles were measured according to the method described previously, both immediately after mixing and 3 and $6 \mathrm{~h}$ later.

Judgment of Precipitation by Visual Observation

Appropriate volumes of $2 \%(\mathrm{w} / \mathrm{v})$ calcium chloride solution or $8.5 \%(\mathrm{w} / \mathrm{v})$ calcium gluconate solution were added to $10 \mathrm{mg} / \mathrm{ml}$ ceftriaxone isotonic sodium chloride solution, to make solutions with a final calcium ion concentration of $2.5 \mathrm{mmol} / \mathrm{l}$. The solutions were gently agitated and stored at $20^{\circ} \mathrm{C}, 25^{\circ} \mathrm{C}$ or $30^{\circ} \mathrm{C}$ for $6 \mathrm{~h}$. The mixtures were observed visually and by stereomicroscope (SZX10, Olympus Co., Ltd.) .

Measurement of Precipitate Weight Appropriate volumes of $2 \%(\mathrm{w} / \mathrm{v})$ calcium chloride solution or $8.5 \%(\mathrm{w} / \mathrm{v})$ calcium gluconate solution were added to $10 \mathrm{ml}$ of $10 \mathrm{mg} / \mathrm{ml}$ ceftriaxone isotonic sodium chloride solution, and the final calcium ion concentrations adjusted to $1.5,2$, or $2.5 \mathrm{mmol} / 1$. The solutions were gently agitated and stored at $25^{\circ} \mathrm{C}$ for $6 \mathrm{~h}$. Samples were weighed after filtration and drying under reduced pressure.

Incompatibility of Ceftriaxone with Commercial Calcium-containing Products Allen et al. ${ }^{10}$ reported that the mixing of an intravenous fluid in an administration set with a secondary additive through a Y-injection site occurs in a 1:1 ratio. To simulate this inline mixing, $100 \mathrm{ml}$ of calcium-containing solutions Bfluid $_{\otimes}$, Bicarbon ${ }^{\circledR}$, Hicaliq ${ }^{\circledR}-2$, Neoparen ${ }_{\circledast}$ No.1, Neoparen ${ }_{\circledast}$ No.2, Solacet ${ }^{\circledR} F$, Solitax ${ }^{\circledR}-\mathrm{H}$, and Solulact ${ }^{\circledR}$ ) were added to $100 \mathrm{ml}$ of $10 \mathrm{mg} / \mathrm{ml}$ ceftriaxone isotonic sodium chloride solution. The so- lutions were gently agitated and stored at $25^{\circ} \mathrm{C}$ for 6 $\mathrm{h}$. The $\mathrm{pH}$ of each solution and the numbers of insoluble microparticles were measured according to the method described previously. The mixtures were also observed visually.

Statistical Analysis The numbers of insoluble microparticles represent the mean of three values, plus or minus the standard deviation. The data on ionic products and K'sp were analyzed by one-way ANOVA with the Dunnet test. The data on incompatibility of ceftriaxone with calcium chloride or calcium gluconate were analyzed by two-way repeated ANOVA followed by Tukey's HSD test; statistical significance was accepted at the $p<0.05$ or $p<0.01$ level.

\section{RESULTS AND DISCUSSION}

\section{Prediction of Incompatibility Using Saturation In-} dex The number of insoluble microparticles increased with increasing ceftriaxone concentration. In particular, the insoluble microparticles with a diameter less than $10 \mu \mathrm{m}$ increased significantly in number when the ceftriaxone concentration of the sample solution was $0.8 \mathrm{mg} / \mathrm{ml}$ or higher (Fig. 1), $\left[\mathrm{Ca}^{2+}\right] \times$ $\left[\mathrm{C}_{18} \mathrm{H}_{15} \mathrm{~N}_{8} \mathrm{O}_{7} \mathrm{~S}_{3}^{3-}\right]$ was $1.79 \times 10^{-6} \mathrm{~mol}^{2} / 1^{2}$, which was 1.1-fold greater than K'sp, that is, the Saturation Index was 1.1. This suggests that microparticles caused by incompatibility of ceftriaxone with calcium seemed to form immediately, when $\left[\mathrm{Ca}^{2+}\right] \times\left[\mathrm{C}_{18} \mathrm{H}_{15}\right.$

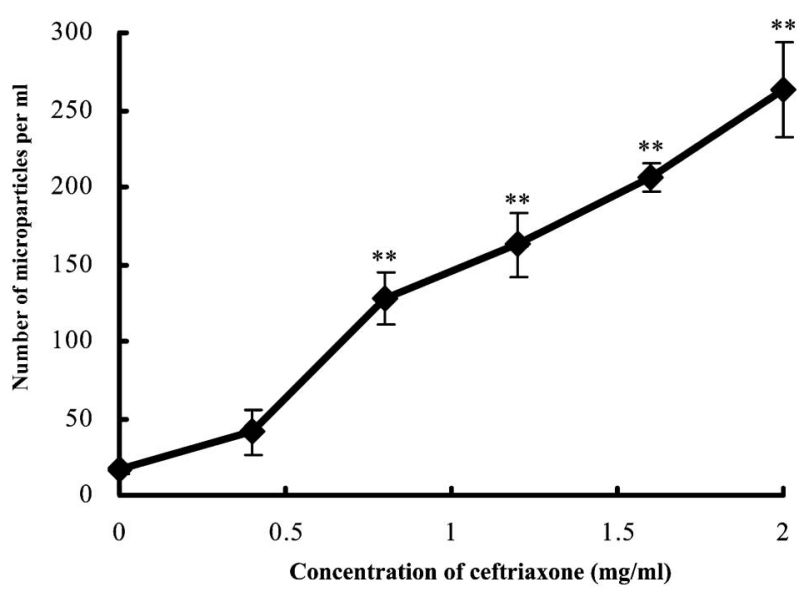

Fig. 1. Number of Insoluble Microparticles with a Diameter Less than $10 \mu \mathrm{m}$ in Ceftriaxone Solution with Added Calcium Chloride Solution Using a Light Obscuration Particle Counter

The number of insoluble microparticles with a diameter less than $10 \mu \mathrm{m}$ $(n=3 \pm$ S.D.) formed when $2 \%(\mathrm{w} / \mathrm{v})$ calcium chloride solution was added to ceftriaxone injection $(0.4-2 \mathrm{mg} / \mathrm{ml})$ made with isotonic sodium chloride solution, and stored at $37^{\circ} \mathrm{C}$ for $24 \mathrm{~h}$. Dunnet test; ${ }^{*} p<0.05$; ${ }^{* *} p<0.01$ 


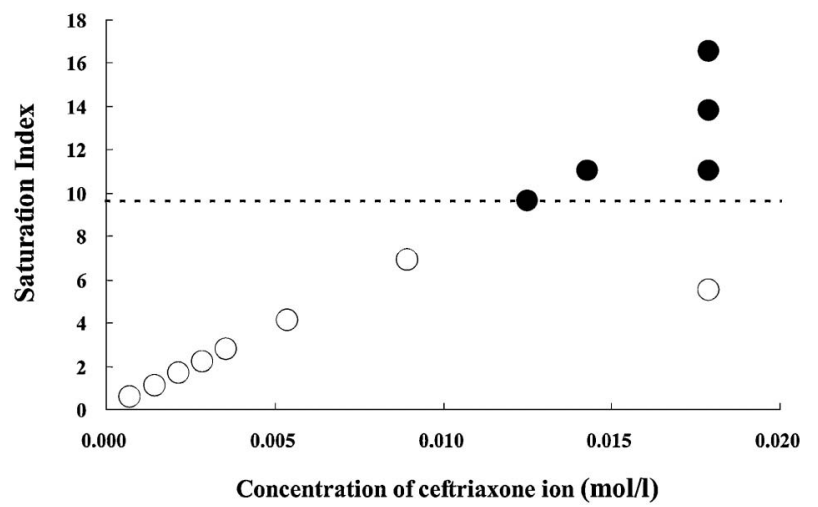

Fig. 2. Saturation Index for the Ceftriaxone-calcium Salt Plotted as a Function of Ceftriaxone Ion Concentration Precipitation formed when $2 \%(\mathrm{w} / \mathrm{v})$ calcium chloride solution was added to ceftriaxone injection $(0.4-10 \mathrm{mg} / \mathrm{ml})$ made with isotonic sodium chloride solution, and stored at $37^{\circ} \mathrm{C}$ for $24 \mathrm{~h}$. veloped precipitate; $\bigcirc$, samples with no visual precipitate after $24 \mathrm{~h}$.

$\mathrm{N}_{8} \mathrm{O}_{7} \mathrm{~S}_{3}^{3-}$ ] exceeded K'sp for ceftriaxone-calcium salt. Some insoluble microparticles were observed even in 0 and/or $0.4 \mathrm{mg} / \mathrm{ml}$ ceftriaxone isotonic sodium chloride solution. This would confirm the previously reported findings of such microparticles in the isotonic sodium chloride solution. ${ }^{11}$

Figure 2 shows the results of visual observation. Precipitation was observed visually when the ceftriaxone concentration of the sample solution was $7 \mathrm{mg} / \mathrm{ml}$ or higher, and $\left[\mathrm{Ca}^{2+}\right] \times\left[\mathrm{C}_{18} \mathrm{H}_{15} \mathrm{~N}_{8} \mathrm{O}_{7} \mathrm{~S}_{3}^{3-}\right]$ was $1.56 \times 10^{-5} \mathrm{~mol}^{2} / 1^{2}$, which was 9.7 -fold greater than K'sp, that is, the Saturation Index was 9.7. Precipitation under conditions in which the Saturation Index between 1 and 10 was not evaluated in the previous article. ${ }^{8)}$

The average concentration of ceftriaxone determined $1-3 \mathrm{~h}$ after dosing, was $898 \mu \mathrm{g} / \mathrm{ml}$ in the cystic bile duct after intravenous administration of $1 \mathrm{~g}$ of ceftriaxone, ${ }^{1)}$ and $\left[\mathrm{Ca}^{2+}\right] \times\left[\mathrm{C}_{18} \mathrm{H}_{15} \mathrm{~N}_{8} \mathrm{O}_{7} \mathrm{~S}_{3}^{3-}\right]$ in the cystic bile duct was $2.01 \times 10^{-6} \mathrm{~mol}^{2} / 1^{2}$, which was 1.2 -fold greater than $\mathrm{K}$ 'sp for ceftriaxone-calcium salt when the calcium ion concentration in the plasma was assumed to be $1.25 \mathrm{mmol} / \mathrm{l}$. In our study, an increase of microparticles caused by incompatibility of ceftriaxone with calcium was confirmed at $1.79 \times 10^{-6}$ $\mathrm{mol}^{2} / \mathrm{l}^{2}$, which was 1.1 -fold greater than $\mathrm{K}$ 'sp for ceftriaxone-calcium salt in vitro. This suggests that biliary concretions or sludge are associated with the interaction of ceftriaxone with calcium-containing products.

Around $9 \mathrm{~g}$ of ionized calcium in the plasma is filtered from the glomerulus ${ }^{12)}$ and $33-67 \%$ of a ceftriaxone dose is excreted in the urine as unchanged drug. ${ }^{1)}$ We could not ignore the possibility of the precipitation of ceftriaxone with plasma calcium ion in the kidney, even if ceftriaxone was not administered simultaneously with calcium-containing products. This would correspond to the reason for the FDA Alert about the death of newborn and premature infants of precipitation in the kidney.

Identification of Precipitate Caused by Incompatibility According to the elementary analysis, it was concluded that the precipitate consisted of ceftriaxone and calcium molecules at a ratio of $1: 1$, as described in previous reports. $\left.{ }^{8}{ }^{13}\right)$ The chemical formula of precipitate predicted from its composition was $\mathrm{C}_{18} \mathrm{H}_{16} \mathrm{~N}_{8} \mathrm{O}_{7} \mathrm{~S}$ Ca.

Incompatibility of Ceftriaxone with Calcium Chloride or Calcium Gluconate Figure 3 shows the number of insoluble microparticles in the sample solution made from $2 \%(\mathrm{w} / \mathrm{v})$ calcium chloride solution after $6 \mathrm{~h}$ storage. Figure 4 shows the number of insoluble microparticles in the sample solution made with $8.5 \%(w / v)$ calcium gluconate solution after $6 \mathrm{~h}$ storage.

In the case of $2 \%(\mathrm{w} / \mathrm{v})$ calcium chloride solution, the number of insoluble microparticles immediately after sample preparation was under the permissible limit in all samples. Their number increased on storage, and by $3 \mathrm{~h}$ after sample preparation exceeded the permissible range at all temperatures when the sample solution contained $\geq 1 \mathrm{mmol} / 1$ calcium ion. At $6 \mathrm{~h}$ after sample preparation the number of insoluble microparticles exceeded the permissible range in a few samples when the sample solutions contained $\geq$ $0.5 \mathrm{mmol} / \mathrm{l}$ calcium ion. The microparticles were fewer at higher temperatures, $6 \mathrm{~h}$ after sample preparation.

In the case of $8.5 \%(\mathrm{w} / \mathrm{v})$ calcium gluconate solution, the number of insoluble microparticles exceeded the permissible range at all temperatures when the sample solution contained $\geq 1 \mathrm{mmol} / 1$ calcium ion by $3 \mathrm{~h}$ after sample preparation, similar to the sample with added calcium chloride. At $6 \mathrm{~h}$ after sample preparation, the number of insoluble microparticles exceeded the permissible range in samples stored at $30^{\circ} \mathrm{C}$ only when the sample solutions contained $\geq 0.5$ $\mathrm{mmol} / \mathrm{l}$ calcium ion. In samples stored at $20^{\circ} \mathrm{C}$ or $25^{\circ} \mathrm{C}$ the number of insoluble microparticles increased on storage and exceeded the permissible range when the sample solution contained $\geq 1 \mathrm{mmol} / 1$ calcium 

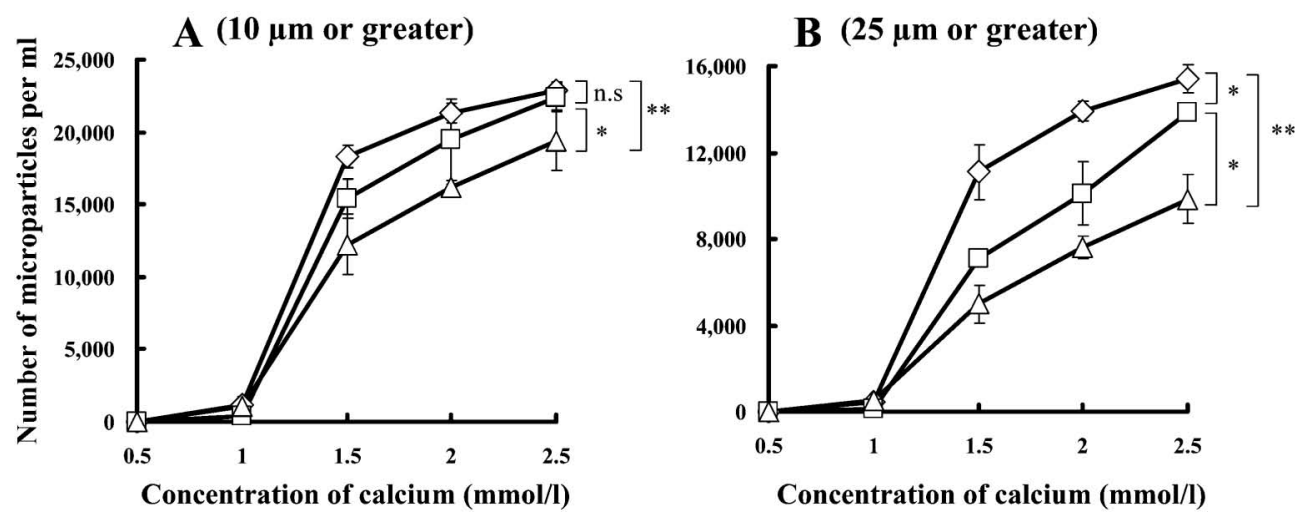

Fig. 3. Number of Insoluble Microparticles in Ceftriaxone Solution with Added Calcium Chloride Solution Using a Light Obscuration Particle Counter

The number of insoluble microparticles with a diameter of $\geq 10 \mu \mathrm{m}$ (A) and $\geq 25 \mu \mathrm{m}$ (B) $(n=3 \pm$ S.D.) formed when $2 \%$ (w/v) calcium chloride solution was added to ceftriaxone injection $(10 \mathrm{mg} / \mathrm{ml})$ made with isotonic sodium chloride solution, and stored at $20^{\circ} \mathrm{C}(\diamond), 25^{\circ} \mathrm{C}(\square)$ and $30^{\circ} \mathrm{C}(\triangle)$ for $6 \mathrm{~h}$. Tukey's HSD test; ${ }^{*} p<0.05 ;{ }^{* *} p<0.01$.

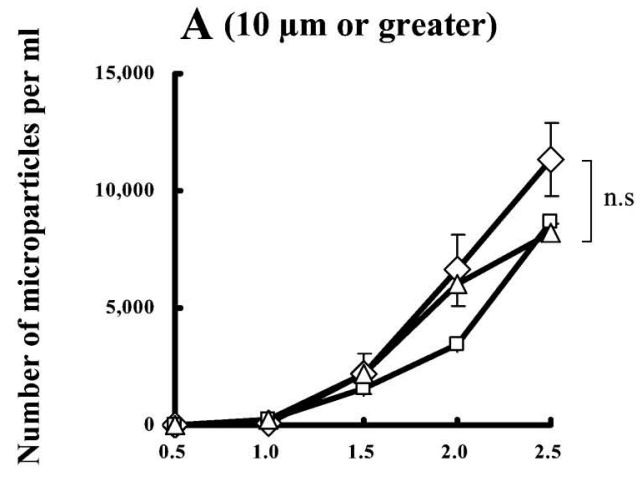

Concentration of calcium $(\mathbf{m m o l} / \mathrm{l})$
B (25 $\mu$ m or greater)

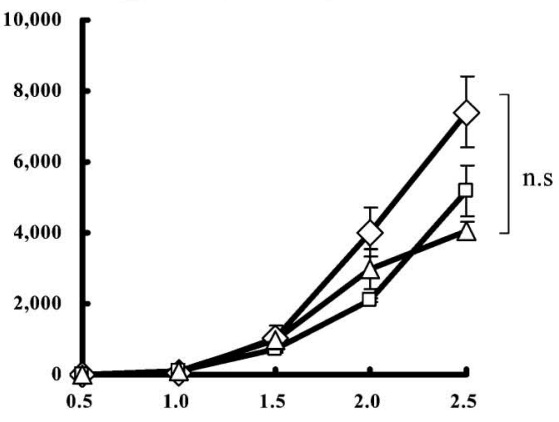

Concentration of calcium $(\mathrm{mmol} / \mathrm{l})$

Fig. 4. Number of Insoluble Microparticles in Ceftriaxone Solution with Added Calcium Gluconate Solution Using a Light Obscuration Particle Counter

The number of insoluble microparticles with a diameter of $\geq 10 \mu \mathrm{m}$ (A) and $\geq 25 \mu \mathrm{m}$ (B) $(n=3 \pm$ S.D.) formed when $8.5 \%$ (w/v) calcium gluconate solution was added to ceftriaxone injection $(10 \mathrm{mg} / \mathrm{ml})$ made with isotonic sodium chloride solution, and stored at $20^{\circ} \mathrm{C}(\diamond), 25^{\circ} \mathrm{C}(\square)$ and $30^{\circ} \mathrm{C}(\triangle)$ for $6 \mathrm{~h}$. Tukey's HSD test; ${ }^{*} p<0.05 ; * * p<0.01$.

ion. There were no significant differences in the number of insoluble microparticles at different temperatures.

In the sample solutions containing calcium chloride, the numbers of insoluble microparticles were significantly higher than those in the solutions containing calcium gluconate at all temperatures. Insoluble particles with a diameter of $\geq 10 \mu \mathrm{m}$ and $\geq 25 \mu \mathrm{m}$ numbered $p<0.01$ in all solutions except those stored at $25^{\circ} \mathrm{C}$ for $3 \mathrm{~h}$, which numbered $p<0.05$. The results of the measurement of sample solutions stored at $25^{\circ} \mathrm{C}$ are shown in Fig. 5.

On visual observation, the surface of the precipitate formed when $2 \%(\mathrm{w} / \mathrm{v})$ calcium chloride solution was added to $10 \mathrm{mg} / \mathrm{ml}$ ceftriaxone isotonic sodium chloride solution was rough; in contrast, in the solution to which $8.5 \%(\mathrm{w} / \mathrm{v})$ calcium gluconate solution was added, the surface was smooth. Under the stereomicroscope, the precipitate in the latter solution was greater than that in the former solution (Fig. 6).

The weight of the precipitate in the solution when 2 $\%(\mathrm{w} / \mathrm{v})$ calcium chloride solution was added to ceftriaxone isotonic sodium chloride solution, was significantly larger than that when $8.5 \%(\mathrm{w} / \mathrm{v})$ calcium gluconate solution was added, as shown in Fig. 7 .

In an examination of the incompatibility of calcium with phosphate, Henry et al. ${ }^{14)}$ reported that calcium chloride and calcium gluconate have different dissociation characteristics. A greater concentration of calci- 

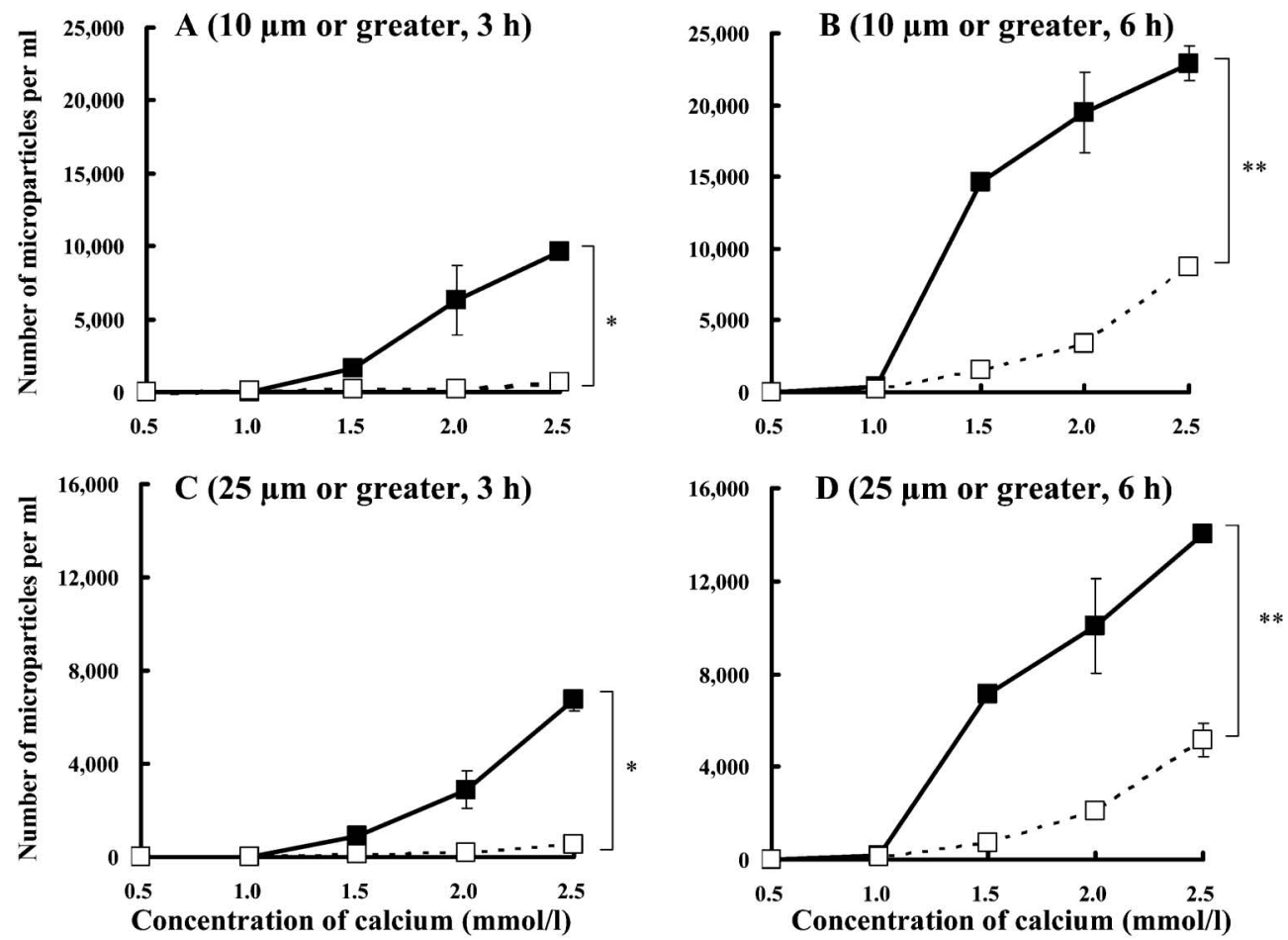

Fig. 5. Number of Insoluble Microparticles in Ceftriaxone Solution with Added Calcium Chloride Solution or Calcium Gluconate Solution Using a Light Obscuration Particle Counter

The number of insoluble microparticles with a diameter of $\geq 10 \mu \mathrm{m}$ (A, B) and of $\geq 25 \mu \mathrm{m}(\mathrm{C}, \mathrm{D})(n=3 \pm$ S.D.) formed when $2 \%$ (w/v) calcium chloride solution $(\square)$ or $8.5 \%(\mathrm{w} / \mathrm{v})$ calcium gluconate solution $(\square)$ was added to ceftriaxone injection $(10 \mathrm{mg} / \mathrm{ml})$ made with isotonic sodium chloride solution, and stored at $25^{\circ} \mathrm{C}$ for $3 \mathrm{~h}(\mathrm{~A}, \mathrm{C})$ or $6 \mathrm{~h}(\mathrm{~B}, \mathrm{D})$. Tukey's HSD test; ${ }^{*} p<0.05 ;{ }^{*} p<0.01$.

A

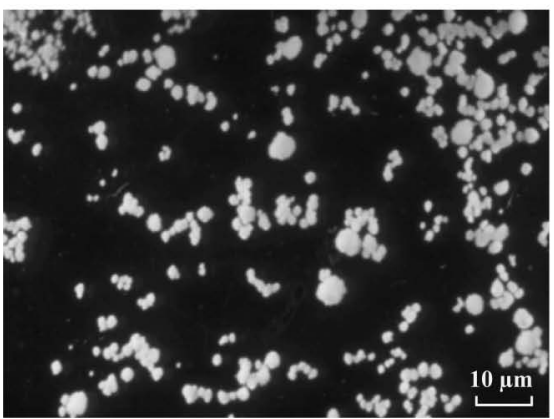

B

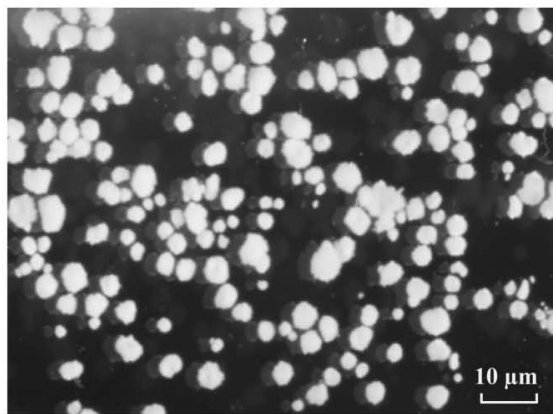

Fig. 6. Stereomicroscope Photographs of Insoluble Microparticles

Insoluble microparticles in the solution of ceftriaxone isotonic sodium chloride solution $(10 \mathrm{mg} / \mathrm{ml})$ mixed with $2 \%$ (w/v) calcium chloride solution (A), or $8.5 \%(\mathrm{w} / \mathrm{v})$ calcium gluconate solution $(\mathrm{B})$, stored at $25^{\circ} \mathrm{C}$ for $6 \mathrm{~h}$.

um gluconate can be mixed with sodium phosphate than is possible for calcium chloride, because the degree of dissociation of calcium gluconate decreases as concentration increases. In other words, when the calcium concentrations were the same, precipitates were formed more easily by ceftriaxone with calcium chloride than with calcium gluconate. It is suggested that the difference is due to the number of insoluble microparticles formed and weight of the precipitate.
Incompatibility of Ceftriaxone with Commercial Calcium-containing Product Solutions Table 1 shows the calcium source and concentration of eight kinds of calcium-containing solutions used in the experiment. Table 2 shows the number of insoluble microparticles in the solutions that mixed $10 \mathrm{mg} / \mathrm{ml}$ ceftriaxone isotonic sodium chloride solution with calcium-containing solutions. The number of insoluble microparticles in all samples was within the per- 
missible range, and no precipitation was observed visually.

The number of insoluble microparticles in the solution of $10 \mathrm{mg} / \mathrm{ml}$ ceftriaxone isotonic sodium chlo-

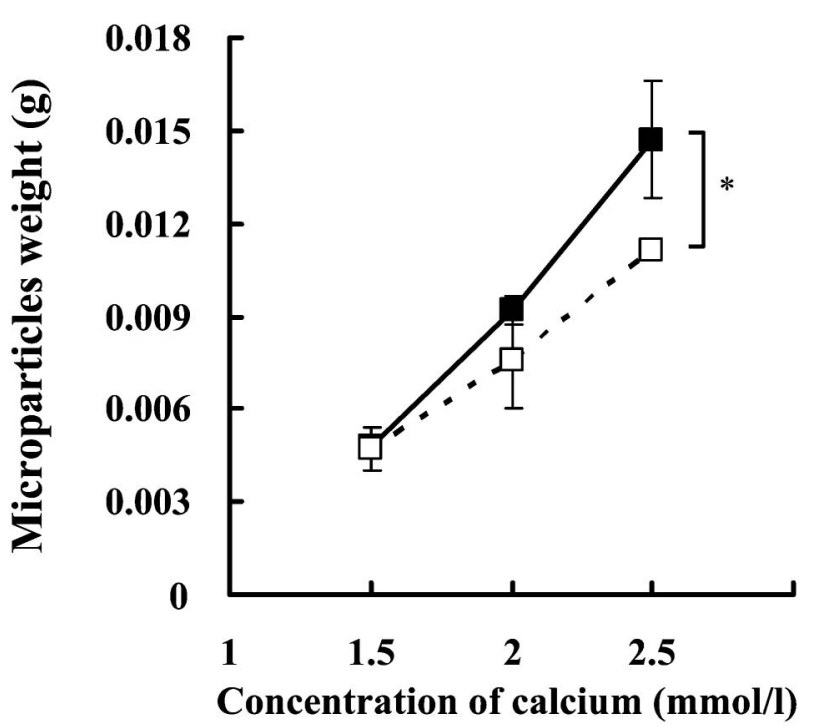

Fig. 7. Weight of the Precipitate

The weight of the precipitate $(n=3 \pm$ S.D. $)$ for each sample to which 2 $\%(\mathrm{w} / \mathrm{v})$ calcium chloride solution $(\boldsymbol{\square})$ or $8.5 \%(\mathrm{w} / \mathrm{v})$ calcium gluconate solution $(\square)$ was added to ceftriaxone injection $(10 \mathrm{mg} / \mathrm{ml})$ made with isotonic sodium chloride solution, and stored at $25^{\circ} \mathrm{C}$ for $6 \mathrm{~h}$ after sample preparation. Tukey's HSD test; ${ }^{*} p<0.05$; ${ }^{* *} p<0.01$. ride solution mixed with Hicaliq $^{\circledR}-2$, which had the highest calcium concentration of all samples, was the same as those in solutions of $10 \mathrm{mg} / \mathrm{ml}$ ceftriaxone isotonic sodium chloride solution mixed with Solacet ${ }^{\circledR} \mathrm{F}$, Solulact ${ }^{\circledR}$ and Bicarbon ${ }^{\circledR}$, which had lower calcium concentrations. The different sources of calcium in the products are thought to be the reason. An organic source of calcium, from calcium gluconate, is contained in Hicaliq ${ }^{\circledR}-2$, while the source of the calcium in Solacet ${ }^{\circledR} \mathrm{F}$, Solulact ${ }^{\circledR}$ and Bicarbon ${ }^{\circledR}$, is inorganic calcium chloride. The number of insoluble

Table 1. pH, Concentration of Calcium Ion and Calcium Source in Eight Different Calcium-containing Solutions Used in the Present Study

\begin{tabular}{lccl}
\hline \hline \multicolumn{1}{c}{ Brand Name } & pH & $\begin{array}{c}\text { Calcium } \\
\text { concentration } \\
(\mathrm{mmol} / \mathrm{l})\end{array}$ & Calcium source \\
\hline Bfluid $_{\otimes}$ & About 6.7 & 2.5 & Calcium chloride \\
Bicarbon $^{\circledR}$ & $6.8 \sim 7.8$ & 1.5 & Calcium chloride \\
Hicaliq $^{\circledR}-2$ & $3.5 \sim 4.5$ & 6.05 & Calcium gluconate \\
Neoparen $_{\otimes}$ No. 1 & About 5.6 & 2 & Calcium chloride \\
Neoparen $_{\otimes}$ No. 2 & About 5.4 & 2.5 & Calcium chloride \\
Solacet $^{\circledR}$ F & $6.0 \sim 7.5$ & 1.5 & Calcium chloride \\
Solitax $^{\circledR}-\mathrm{H}$ & $5.7 \sim 6.5$ & 2.5 & Calcium chloride \\
Solulact $^{\circledR}$ & $6.0 \sim 7.5$ & 1.5 & Calcium chloride
\end{tabular}

Table 2. Number of Insoluble Microparticles in Ceftriaxone Solution with Added Calcium-containing Solutions Using a Light Obscuration Particle Counter

\begin{tabular}{|c|c|c|c|c|}
\hline \multirow{2}{*}{ Brand Name } & \multirow{2}{*}{ Particle size } & \multicolumn{3}{|c|}{ Number of insoluble microparticles per ml (mean \pm S.D. $)$} \\
\hline & & $\begin{array}{l}\text { After preparation } \\
\text { immediately }\end{array}$ & $3 \mathrm{~h}$ after preparation & $6 \mathrm{~h}$ after preparation \\
\hline \multirow[t]{2}{*}{ Bfluid ${ }_{\otimes}$} & $10 \mu \mathrm{m}$ or greater & $7.00 \pm 2.00$ & $8.00 \pm 4.36$ & $7.00 \pm 0.00$ \\
\hline & $25 \mu \mathrm{m}$ or greater & $0.67 \pm 0.58$ & $1.00 \pm 1.00$ & $0.67 \pm 1.15$ \\
\hline \multirow[t]{2}{*}{ Bicarbon $^{\circledR}$} & $10 \mu \mathrm{m}$ or greater & $12.33 \pm 4.04$ & $7.67 \pm 2.52$ & $9.67 \pm 2.52$ \\
\hline & $25 \mu \mathrm{m}$ or greater & $2.00 \pm 2.00$ & $0.00 \pm 0.00$ & $2.00 \pm 1.73$ \\
\hline \multirow[t]{2}{*}{ Hicaliq $^{\circledR}-2$} & $10 \mu \mathrm{m}$ or greater & $10.33 \pm 4.73$ & $5.50 \pm 0.71$ & $10.33 \pm 8.39$ \\
\hline & $25 \mu \mathrm{m}$ or greater & $2.00 \pm 2.00$ & $1.33 \pm 0.58$ & $0.67 \pm 0.58$ \\
\hline \multirow[t]{2}{*}{ Neoparen $\otimes$ No. 1} & $10 \mu \mathrm{m}$ or greater & $7.33 \pm 3.06$ & $10.00 \pm 5.29$ & $13.67 \pm 4.04$ \\
\hline & $25 \mu \mathrm{m}$ or greater & $1.33 \pm 1.15$ & $1.33 \pm 0.58$ & $1.00 \pm 0.00$ \\
\hline \multirow[t]{2}{*}{ Neoparen $_{\otimes}$ No. 2} & $10 \mu \mathrm{m}$ or greater & $10.67 \pm 2.31$ & $11.00 \pm 7.81$ & $15.67 \pm 8.33$ \\
\hline & $25 \mu \mathrm{m}$ or greater & $1.33 \pm 1.15$ & $1.67 \pm 2.08$ & $1.00 \pm 0.00$ \\
\hline \multirow[t]{2}{*}{ Solacet ${ }^{\circledR} \mathrm{F}$} & $10 \mu \mathrm{m}$ or greater & $11.33 \pm 7.02$ & $9.33 \pm 4.51$ & $9.33 \pm 3.21$ \\
\hline & $25 \mu \mathrm{m}$ or greater & $1.33 \pm 1.15$ & $1.67 \pm 1.53$ & $1.00 \pm 1.00$ \\
\hline \multirow[t]{2}{*}{ Solitax ${ }^{\circledR}-H$} & $10 \mu \mathrm{m}$ or greater & $8.67 \pm 2.52$ & $7.33 \pm 4.62$ & $10.67 \pm 4.51$ \\
\hline & $25 \mu \mathrm{m}$ or greater & $1.00 \pm 0.00$ & $0.67 \pm 0.58$ & $0.33 \pm 0.58$ \\
\hline \multirow[t]{2}{*}{ Solulact ${ }^{\circledR}$} & $10 \mu \mathrm{m}$ or greater & $7.00 \pm 2.00$ & $8.00 \pm 2.65$ & $11.00 \pm 3.61$ \\
\hline & $25 \mu \mathrm{m}$ or greater & $0.67 \pm 0.58$ & $1.33 \pm 0.58$ & $1.33 \pm 0.58$ \\
\hline
\end{tabular}

The number of insoluble microparticles with a diameter of $\geq 10 \mu \mathrm{m}$ and $\geq 25 \mu \mathrm{m}(n=3 \pm$ S.D.) formed when calcium-containing solutions were added to ceftriaxone injection $(10 \mathrm{mg} / \mathrm{ml})$ made with isotonic sodium chloride solution, and stored at $25^{\circ} \mathrm{C}$ for 3 or $6 \mathrm{~h}$. 
microparticles is believed to be less than that predicted using the Saturation Index, because the dissociation characteristics of the calcium from gluconate and from chloride are different.

Although the calcium ion concentrations in Solitax $^{\circledR}-\mathrm{H}$, Neoparen ${ }_{\circledast}$ No.2 and Bfluid ${ }_{\circledast}$ were the same, the number of insoluble microparticles was highest in Neoparen ${ }_{\circledast}$ No.2. The Saturation Index, calculated from the $\mathrm{pH}$ of the mixed solutions, was Hicaliq $^{{ }^{\circledR}}-2 \quad$ (9.07) $>$ Bfluid $_{\circledast} \quad(6.93)>$ Solitax $^{\circledR}-\mathrm{H}$ (6.78) $>$ Neoparen $_{\circledast}$ No.2 (6.35) $>$ Neoparen $_{\circledast}$ No.1 (5.27) $>$ Bicarbon $^{\circledR}$ (4.16) $>$ Solacet $^{\circledR} \mathrm{F}$ (4.15) > Solulact ${ }^{\circledR}$ (4.12) . The number of insoluble microparticles in the mixed solutions did not follow this order. High concentrations of glucose in the calcium-containing solutions may also affect the calcium dissociation; further examination is therefore necessary.

In this study, the number of insoluble microparticles in all samples was within the permissible range, and no precipitation was observed visually. When the Saturation Index of the solution was $\geq 1.0$, however, the number of insoluble microparticles increased due to the incompatibility of ceftriaxone with calcium, as shown by examination of the ionic product and K'sp. Therefore, when selecting ceftriaxone for the treatment of an infectious disease, co-administration with infusion solutions including calcium should be avoided. The possibility of causing a serious adverse event due to ceftriaxone-calcium complex formation in vivo, for example, by co-administration of multivitamins containing vitamin $\mathrm{D}$ or total parenteral nutrition containing high concentrations of calcium, or in conditions where the ionic calcium concentration in the plasma is increased (such as in the presence of malignant tumors), cannot be excluded, even if ceftriaxone is administered by another route.

\section{CONCLUSION}

These results suggested that ceftriaxone should not be co-administered with calcium-containing products, even if no precipitation is visible, because there may still be insoluble microparticles caused by incompatibility in solutions of Saturation Index $>1$. We cannot exclude the possibility of a serious adverse event arising, based on ceftriaxone-calcium complex formation in vivo, when ceftriaxone is co-administered with multivitamins including vitamin $\mathrm{D}$, with total parenteral nutrition including high concentrations of calcium, and in conditions where the ionic calcium concentration in the plasma rises, even if ceftriaxone is administered by another route.

\section{REFERENCES}

1) Rochephin ${ }^{\circledR}$ Prescribing Information, Roche Pharmaceuticals in the U.S., 2008.

2) FDA Safety Alert. Information for healthcare professionals: Ceftriaxone (marketed as Rocephin). Rockville: Food and Drug Administration, Rockville, MD, USA, September 11 (2007).

3) Palanduz A., Yalçin I., Tonguç E., Güler N., Oneş U., Salman N., Somer A., J. Clin. Ultrasound, 28, 166-168 (2000).

4) Bor O., Dinleyici E. C., Kebapci M., Aydogdu S. D., Pediatr. Int., 46, 322-324 (2004).

5) Ozturk A., Kaya M., Zeyrek D., Ozturk E., Kat N., Ziylan S. Z., Acta Radiol., 46, 112116 (2005).

6) Biner B., Oner N., Celtik C., Bostancioğlu M., Tunçbilek N., Güzel A., Karasalihoğlu S., J. Clin. Ultrasound, 34, 217-222 (2006) .

7) Bickford C. L., Spencer A. P., Pharmacotherapy, 25, 1389-1395 (2005).

8) Shiffman M. L., Keith F. B., Moore E. W., Gastroenterology, 99, 1772-1778 (1990).

9) “Japanese Pharmacopoeia, 15th edn," Hirokawa Book Co., Tokyo, 2006, pp. B566-569.

10) Allen L. V. Jr., Levinson R. S., Phisutsinthop D., Am. J. Hosp. Pharm., 34, 939-943 (1977).

11) Kuramoto $K$, Shoji $T$, Nakagawa $Y$., Yakugaku Zasshi, 126, 289-295 (2006) .

12) “Goodman and Gilman's Pharmacological Basis of Therapeutics 10th edn," Hirokawa Book Co., Tokyo, 2003, pp. 2190-2191.

13) Park H. Z., Lee S. P., Schy A. L., Gastroenterology, 100, 1665-1670 (1991).

14) Henry R. S., Jurgens R. W. Jr., Sturgeon R., Athanikar N., Welco A., Leuven M. V., Am. J. Hosp. Pharm., 37, 673-674 (1980) . 